\title{
High-Pressure, High-
} Temperature Thermal Hydraulic Test Facility for Nuclear-Renewable Hybrid Energy System Studies; Facility Design Description and Status Report

James E. O'Brien, Su-Jong Yoon, Piyush Sabharwall, Shannon Bragg-Sitton September 2017

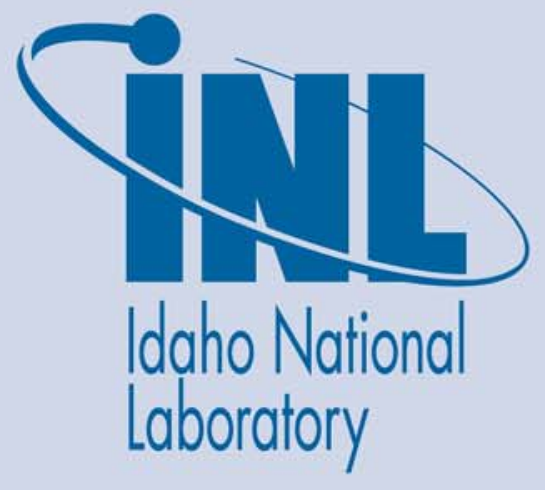

The INL is a U.S. Department of Energy National Laboratory operated by Battelle Energy Alliance 


\section{DISCLAIMER}

This information was prepared as an account of work sponsored by an agency of the U.S. Government. Neither the U.S. Government nor any agency thereof, nor any of their employees, makes any warranty, expressed or implied, or assumes any legal liability or responsibility for the accuracy, completeness, or usefulness, of any information, apparatus, product, or process disclosed, or represents that its use would not infringe privately owned rights. References herein to any specific commercial product, process, or service by trade name, trade mark, manufacturer, or otherwise, does not necessarily constitute or imply its endorsement, recommendation, or favoring by the U.S. Government or any agency thereof. The views and opinions of authors expressed herein do not necessarily state or reflect those of the U.S. Government or any agency thereof. 


\section{High-Pressure, High-Temperature Thermal Hydraulic Test Facility for Nuclear-Renewable Hybrid Energy System Studies; Facility Design Description and Status Report}

James E. O'Brien, Su-Jong Yoon, Piyush Sabharwall, Shannon Bragg-Sitton

September 2017

Idaho National Laboratory

Nuclear Science and Technology

Idaho Falls, Idaho 83415

http://www.inl.gov

Prepared for the

U.S. Department of Energy

Office of Nuclear Energy

Under DOE Idaho Operations Office

Contract DE-AC07-05ID14517 

Nuclear Science and Technology

\section{High-Pressure, High-Temperature Thermal Hydraulic Test Facility for Nuclear-Renewable Hybrid Energy System Studies; Facility Design Description and Status Report}

INL/EXT-17-43269

Revision 0

September 2017

Approved by:
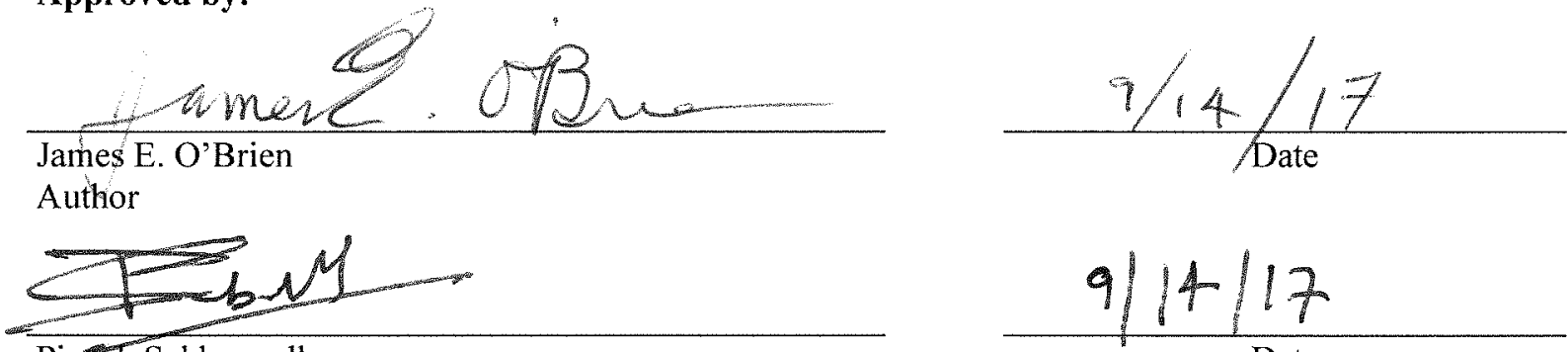

Piytsh Sabharwall

Reviewer
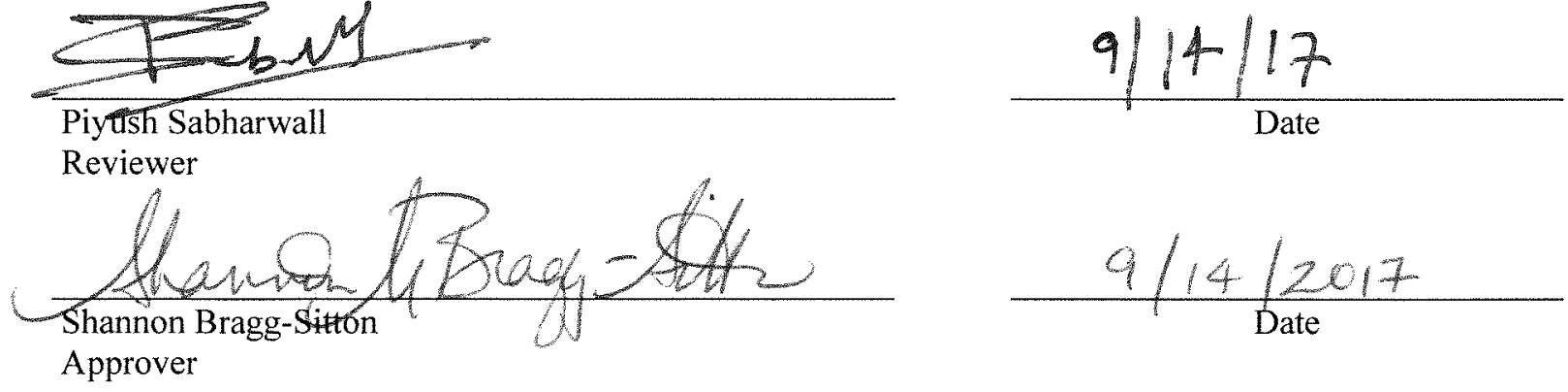



\section{EXECUTIVE SUMMARY}

A high-pressure, high-temperature water flow loop has been designed at Idaho National Laboratory (INL) for deployment in the INL Dynamic Energy Transport and Integration Laboratory (DETAIL) within the Energy Systems Laboratory (ESL) D100 northwest high bay. The high-pressure water loop will operate at Pressurized Water Reactor (PWR) conditions. This loop is the first of three thermally coupled flow loops that will comprise the Advanced Reactor Technology Integral System Test (ARTIST) facility. The ARTIST facility will ultimately include a high-temperature helium loop and a liquid salt loop, in addition to the PWR loop. It will support experimental research on nuclear-renewable hybrid energy systems as well as advanced reactor technology topics. Within DETAIL, the water flow loop will also serve as a thermal energy source, emulating a reactor system. The loop will be thermally integrated with co-located energy systems including a thermal energy transport loop, thermal energy storage system, and a $25 \mathrm{~kW}$ high-temperature electrolysis system for hydrogen production. DETAIL will include additional energy systems such as an integrated microgrid and renewable energy systems including solar photovoltaics. The electrically heated flow loop will be dynamically controlled to simulate nuclear fuel behavior under normal and off-normal operating conditions. DETAIL will be designed for characterization of complex system dynamics. The various components will be interfaced with Digital Real-Time Simulators for supervisory control and dynamic simulation of complete systems.

Construction of the water loop facility has been subdivided into two Phases. Phase 1 includes installation of general-purpose laboratory infrastructure/support systems necessary to perform any significant hardware testing in the High Bay. Scheduled to be completed by the end of FY17, Phase 1 covers installation of cable trays and supports, electrical conduit, a DI water system, drain lift station and the concrete pad for a chiller that will be located outside of the laboratory. Phase 2 includes the detailed design and final assembly of the flow loop, supporting structures and personnel platforms, the chiller and associated piping. As of September, 2017, the final detailed design of the flow loop is complete.

Funding for Phase 2 procurement, assembly, system operability checkout, shakedown testing and initial operation of the flow loop is requested for FY18. 


\section{ACKNOWLEDGEMENTS}

The authors would like to acknowledge the Nuclear Hybrid Energy Program Nuclear System Design and Analysis Division for supporting the development of the high-pressure, high-temperature thermal hydraulic test facility.

This report was prepared as an account of work sponsored by an agency of the United States Government. Neither the United States Government nor any agency thereof, nor any of their employees, makes any warranty, express or implied, or assumes any legal liability or responsibility for the accuracy, completeness, or usefulness of any information, apparatus, product, or process disclosed, or represents that its use would not infringe privately owned rights. Reference herein to any specific commercial product, process, or service by trade name, trademark, manufacturer, or otherwise, does not necessarily constitute or imply its endorsement, recommendation, or favoring by the United States Government or any agency thereof. The views and opinions of authors expressed herein do not necessarily state or reflect those of the United States Government or any agency thereof. 


\section{CONTENTS}

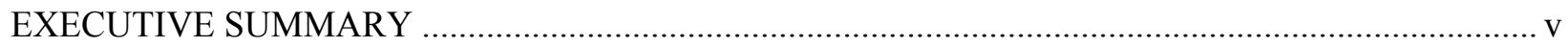

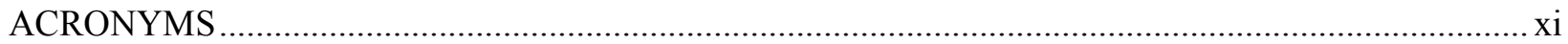

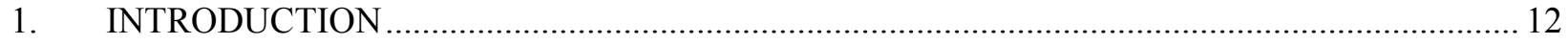

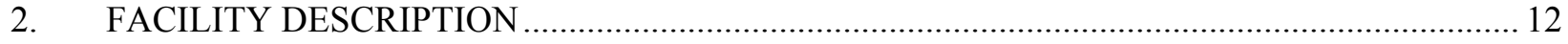

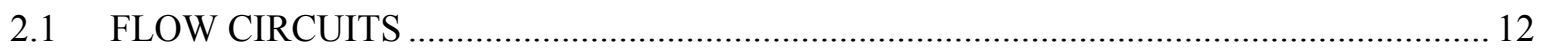

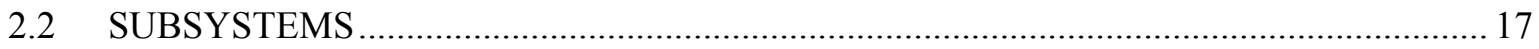

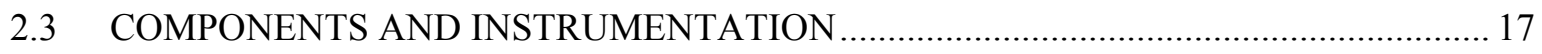

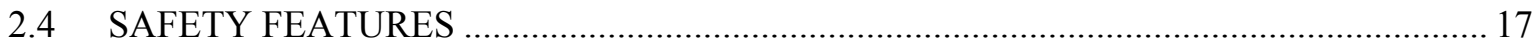

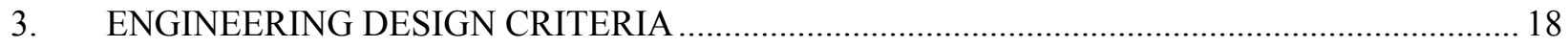

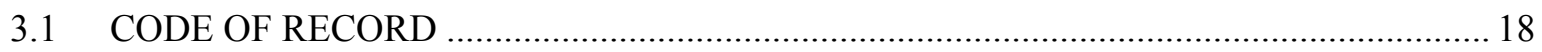

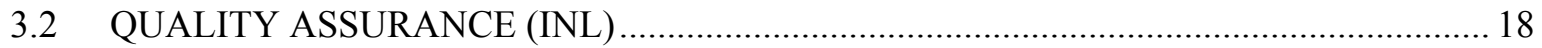

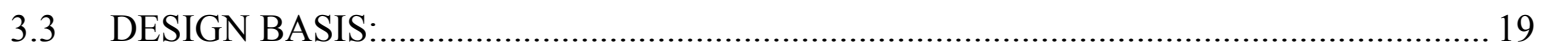

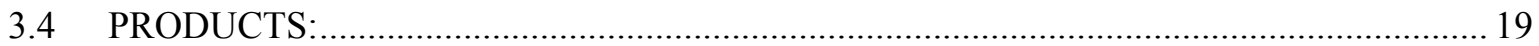

4. INTERFACES TO CO-LOCATED SYSTEMS AND DETAIL ….......................................... 19

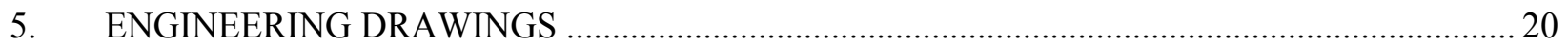

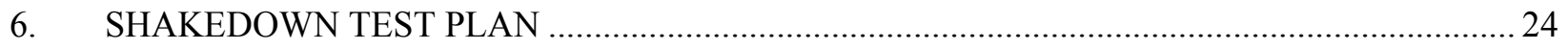

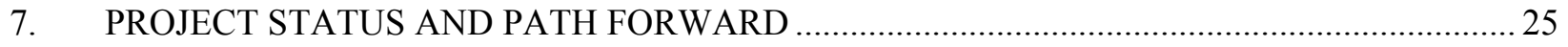

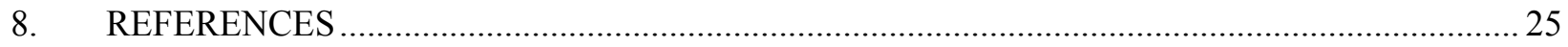

APPENDIX A. COMPONENT AND INSTRUMENTATION DETAILS …........................................ 26

\section{FIGURES}

FIGURE 1. Piping and instrumentation diagram for the high-pressure thermal hydraulic test facility. 14

FIGURE 2. P\&ID with the forced circulation loop highlighted........................................................ 15

FIGURE 3. P\&ID with the natural circulation loop highlighted........................................................ 16

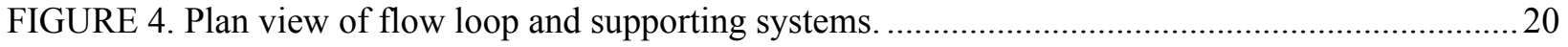

FIGURE 5. Elevation view of flow loop and supporting systems. .....................................................21

FIGURE 6. Isometric view of flow loop and supporting systems. ...................................................22

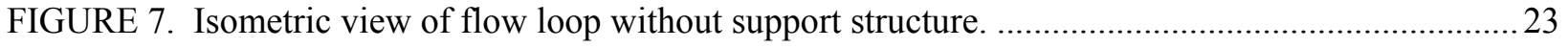

FIGURE 8. Rotated isometric view of flow loop without support structure. ........................................24 


\section{TABLES}

TABLE 2-1. Primary loop valve positions for forced and natural circulation modes. ............................. 13

TABLE A-1. Component and Instrumentation Descriptions and Specifications. ..................................26 


\title{
ACRONYMS
}

\author{
INL Idaho National Laboratory \\ ESL Energy Systems Laboratory \\ ARTIST Advanced Reactor Technology Integral System Test \\ DETAIL Dynamic Energy Transport and Integration Laboratory \\ P\&ID Piping and Instrumentation Diagram \\ ASME American Society of Mechanical Engineers \\ LI Laboratory Instruction \\ PPE Personal Protective Equipment \\ BEA Battelle Energy Alliance \\ HPW High pressure water \\ CAD Computer Aided Design
}




\section{INTRODUCTION}

A high-pressure, high-temperature water flow loop has been designed at Idaho National Laboratory (INL) for deployment in the INL Dynamic Energy Transport and Integration Laboratory (DETAIL) within the Energy Systems Laboratory (ESL) D100 northwest high bay. The water loop will operate at Pressurized Water Reactor (PWR) conditions. This loop is the first of three thermally coupled flow loops that will comprise the Advanced Reactor Technology Integral System Test (ARTIST) facility. The ARTIST facility will ultimately include a high-temperature helium loop and a liquid salt loop, in addition to the PWR loop. More detailed descriptions of ARTIST and its research objectives are provided in references [1 - 4]. It will support experimental research on nuclear-renewable hybrid energy systems as well as advanced reactor technology topics. Within DETAIL, the water flow loop will serve as a thermal energy source, emulating a reactor system. The loop will be thermally integrated with co-located energy systems including a thermal energy transport loop, thermal energy storage system, and a $25 \mathrm{~kW}$ high-temperature electrolysis system for hydrogen production. DETAIL will include additional energy systems such as an integrated microgrid and renewable energy systems including solar photovoltaics. The electrically heated flow loop will be dynamically controlled to simulate nuclear fuel behavior under normal and off-normal operating conditions. DETAIL will be designed for characterization of complex system dynamics. The various components will be interfaced with Digital Real-Time Simulators for supervisory control and dynamic simulation of complete systems.

\section{FACILITY DESCRIPTION 2.1 Flow Circuits}

The overall piping and instrumentation diagram (P\&ID) of the PWR flow loop is provided in Fig. 1. There are two primary modes of operation for the flow loop: forced circulation and natural circulation. The primary flow loop for forced circulation is highlighted in green in Fig. 2. Nominal temperatures and pressures, and the flow rate are also indicated on Fig. 2 for the forced circulation base case. Valve positions for forced and natural circulation are listed in Table 2-1. The flow loop includes a hightemperature section and a low-temperature section, with heat recuperation. This design was chosen for several reasons:

1) Less intense specification requirements for circulation pump, main flow meter, valves, piping, and pipe fittings in low-temperature section.

2) The recuperator will be an advanced-technology printed circuit heat exchanger (PCHE), allowing for performance evaluation of these heat exchangers under prototypical PWR conditions.

3) This design enables support of natural circulation testing with applicability to advanced reactor operations and safety performance.

4) The recuperator and chiller enable rapid cool-down of the flow system when needed.

5) The high-power primary heater enables supply of significant high-temperature process heat to colocated hybrid systems.

6) The chiller heat rejection allows for much better loop temperature control and continuous loop operation at low temperature without a slow increase in temperature from pump heating.

Forced circulation flow is driven by the circulation pump shown in the lower right of the P\&ID. Water at $50^{\circ} \mathrm{C}, 15 \mathrm{MPa}$ flows up through 2-inch schedule 160 stainless steel piping past a pressure transducer (HPW-PT-01), a thermocouple (HPW-TC-01), a conductivity sensor (HPW-CN-01) and a turbine flow meter (HPW-FM-01). Base case nominal flow rate is $1130 \mathrm{~kg} / \mathrm{hr}$, which corresponds to $5 \mathrm{gal} / \mathrm{min}$ at $50^{\circ} \mathrm{C}$ and $15 \mathrm{MPa}$. At the first tee, for forced circulation, motor-operated valve HPW-MOV-01 is closed and the water flows through valve HPW-MOV-02 to the cold side of the recuperator where it is preheated to approximately $225^{\circ} \mathrm{C}$ by recuperative heat exchange with the water returning from the high-temperature section. Recuperator heat duty for the base case is approximately $285 \mathrm{~kW}$. Downstream of the 
recuperator, water flows through a replaceable pipe section that will house conductivity and dissolved oxygen sensors, a flowmeter, and an orifice plate during natural circulation testing. The flow then enters the electrically powered auxiliary heater. For the base case, the auxiliary heater requirement will be $95 \mathrm{~kW}$.

However, this heater has been sized for higher flow rate cases and to supply high-temperature process heat to co-located experiments within the overall DETAIL infrastructure.

Hence, it has been specified at a 175 $\mathrm{kW}$ rating. Water leaves the auxiliary heater at the maximum flow loop temperature of $325^{\circ} \mathrm{C}$. Note that the saturation temperature for water at $15 \mathrm{MPa}$ is $342^{\circ} \mathrm{C}$, so the water remains in the liquid phase even at $325^{\circ} \mathrm{C}$. After exiting the auxiliary heater, the flow enters the hightemperature test section. The specific design of this section will depend on the particular experimental campaign in progress such as corrosion studies, flow-induced vibration, natural circulation studies, etc. The test section will be interchangeable, with grayloc fittings for easy changeout. Downstream of the high-temperature test section, the primary water flows through valves HPW-MOV-07 and HPW-MOV-04 and enters the hot side of the recuperative heat exchanger. It exits the heat exchanger at approximately $120^{\circ} \mathrm{C}$ and then flows into the chiller heat exchanger where the water is cooled back down to $50^{\circ} \mathrm{C}$. The air-cooled chiller that provides secondary coolant (glycol) for the chiller heat exchanger has been specified for a duty of up to $200 \mathrm{~kW}$ (60 ton). For the nominal baseline case, with no process heat delivery, the heat duty for the chiller will be about $95 \mathrm{~kW}$. The heat duty specification of $200 \mathrm{~kW}$ will provide significant margin to support higher flow rate cases. The primary flow then enters the suction side of the circulation pump to complete the loop.

For natural circulation studies, the primary forced circulation and secondary natural circulation flow loops are highlighted in Fig. 3. The primary loop is shown in green and the natural circulation secondary loop is shown in red. Nominal flow rates, temperatures and pressures are shown at various stations on the figure for the natural circulation base case. The primary and secondary loops in this case interact only thermally via the recuperator heat exchanger which in this case serves as a heat sink for the natural circulation loop.

The driving buoyancy forces for the natural circulation loop are generated by the high-temperature test section for heat addition and the recuperator for heat rejection. The high-temperature test section in this case will consist of an array of electrically heated simulated fuel rods arranged in a prototypical geometry with high heat flux capability. In the natural circulation loop, buoyancy-driven flow exits the top of the heated high-temperature test section at approximately $280^{\circ} \mathrm{C}$, flows upward past valve HPW-MOV-06 and enters the top of the recuperator. The water is cooled to about $213^{\circ} \mathrm{C}$ in the recuperator. It then flows downward into the natural circulation instrumentation section that includes the dissolved oxygen and conductivity sensors as well as a low pressure-drop, low-flow flow meter. An orifice plate can also be inserted into this section to simulate a range of loss coefficients. 


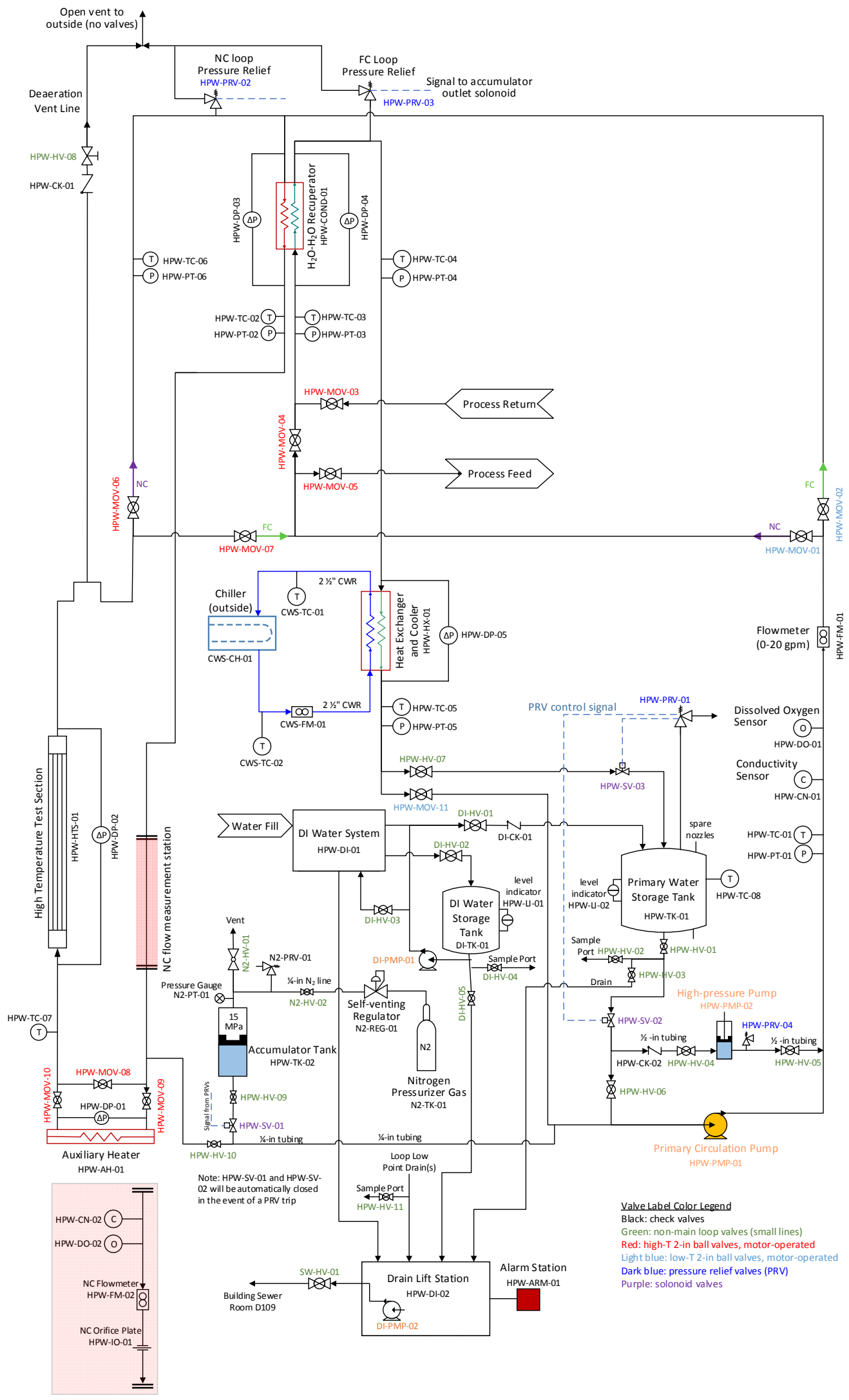

Figure 1. Piping and instrumentation diagram for the high-pressure thermal hydraulic test facility. 


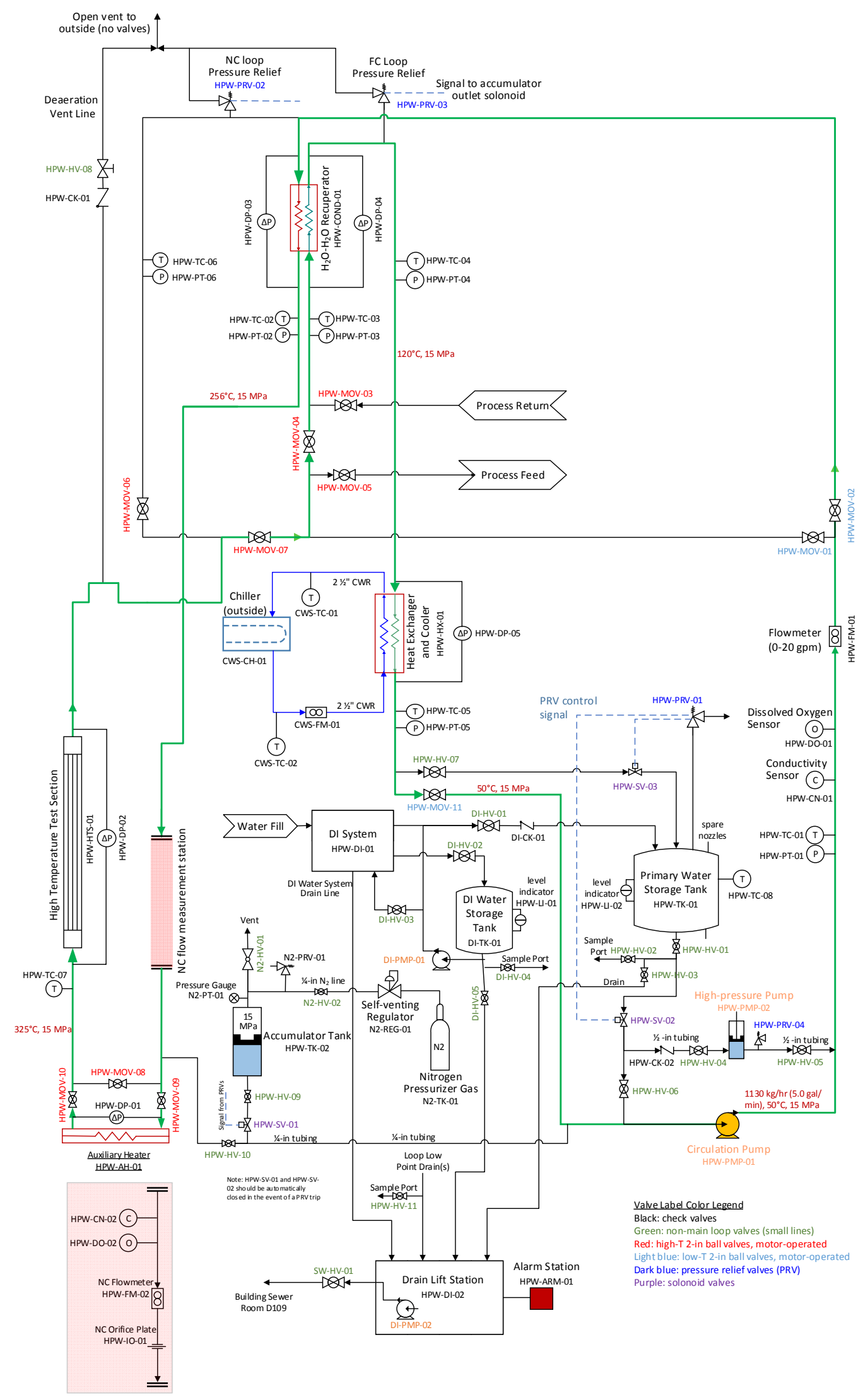

Figure 2. P\&ID with the forced circulation loop highlighted. 


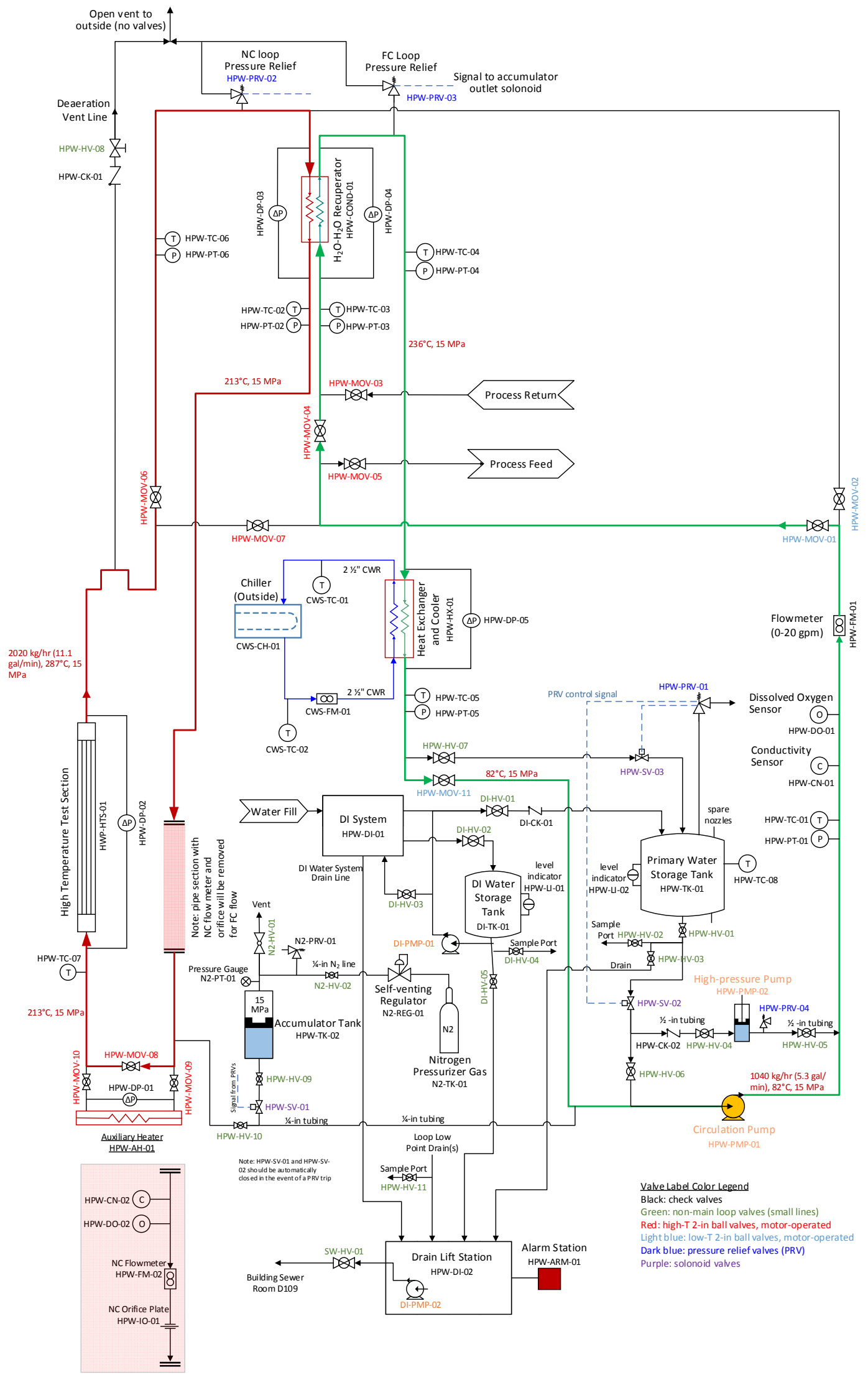

Figure 3. P\&ID with the natural circulation loop highlighted. 


\subsection{Subsystems}

Water Chemistry. The water flow loop includes a chemistry control system. The working fluid for the flow loop is deionized water with a supply conductivity value of $1 \mu \mathrm{S} / \mathrm{cm}$ or lower and effectively neutral $\mathrm{pH}$. This water chemistry specification will be supplied and maintained using a reverse osmosis deionized water system. Instrumentation for the water loop will include in-line conductivity and dissolved oxygen sensors. Both of these sensors will be installed in the low-temperature part of the water loop.

Chiller. Primary system heat rejection is achieved using an air-cooled chiller unit to be located outside the laboratory. To prevent freezing, the working fluid on the secondary side of the chiller will be glycol. The chiller system will include coolant flow rate and temperature control.

Deaeration. For PWR systems, minimization of dissolved oxygen to $<5 \mathrm{ppb}$ is desired. Primary system deaeration will be achieved through heating of water flowing in the loop at ambient pressure. The solubility of air in water at atmospheric pressure drops by nearly two orders of magnitude from the freezing point to the boiling point. For deaeration, the water will be heated to a temperature just below the boiling point. Dissolved air will be released from the system at the deaeration vent which is located downstream of the heated section. Valve HPW-HV-08 will be opened during deaeration. The vented air is released to the outside vent.

Drain Lift Station. The high-bay laboratory D100 in ESL does not have floor drains in the vicinity of the experiment skid. Therefore, a drain lift station will be used to collect drain water in a sump and pump it to a floor drain located in the boiler room along the south wall of the high bay. The drain lines will be supported underneath cable trays.

Pressurization. The flow loop will be initially pressurized to operating pressures up to $15 \mathrm{MPa}$ using the high-pressure pump, designated HPW-PMP-02 in the diagram. Pressure maintenance during system operation will be achieved using an accumulator tank. For loop pressurization, the accumulator tank pressure will be pre-set to an initial pressure of approximately $25 \%$ of the final loop operating pressure using nitrogen gas cylinder and self-venting regulator N2-REG-01. For full loop pressurization, the highpressure pump HPW-PMP-02 will establish the full loop operating pressure with valve N2-HV-02 closed and valve HPW-HV-09 open such that the accumulator also achieves the full system operating pressure. At this point, the N2 regulator will also be set to the full loop operating pressure and valve N2-HV-02 will be opened. The loop can now be operated at full pressure. The use of the accumulator and the regulated nitrogen pressure will assure that the system pressure will stay constant even during heating and cooling of the water in the system. The accumulator also serves as a buffer that minimizes the effects of any pressure transients or water hammer. The regulator will be self-venting so that it will vent $\mathrm{N}_{2}$ if the pressure in the system rises, thereby maintaining a constant system pressure. Note that during natural circulation testing, the primary flow loop and the natural circulation flow loop are independent and must both be pressurized. For these cases, valve HPW-HV-10 must be in the open position.

\subsection{Components and Instrumentation}

A comprehensive list and description of system components and instrumentation is provided in Table A1 of Appendix 1. Major components include: circulation pump, high-pressure pump, accumulator and nitrogen gas pressurizer, recuperative heat exchanger, chiller and chiller heat exchanger, natural circulation measurement station, high-temperature test section, auxiliary heater, DI water system, and drain lift station.

\subsection{Safety Features}

The primary safety concern related to this facility is high pressure. This issue is addressed in the design by assuring compliance with the ASME 31.3 Process Piping Code and through the use of AMSE-certified pressure relief valves (PRVs). There are two PRVs on the process piping (HPW-PRV-02 and HPWPRV-03) that will be set at the system design pressure. In the natural circulation mode, there are two 
independent flow loops. Therefore, two PRVs are required in order to support the natural circulation mode of operation. When operating the flow loop at design conditions, release of fluid from a PRV may result in flashing of hot liquid water to steam. The PRV vent lines will be exhausted to the outside and will be sized to handle steam. The two PRVs on the process piping will be configured to generate a signal to close solenoid valve HPW-HV-01 in the event that one of these PRVs opens. This action will prevent the accumulator from maintaining system pressure in the event of a PRV release. Restoration of system pressure will require manual intervention after evaluation of the PRV release event has been completed. There is also a PRV (HPW-PRV-01) on the low-pressure primary water storage tank that will be set at a value consistent with its pressure rating. PRV (HPW-PRV-04) is located near the outlet of the high-pressure pump. It will protect the pump from over-pressurization in the event that valve HPW-HV05 is inadvertently closed during pump operation. The high-pressure pump is only used for initial loop and accumulator pressurization.

Loop process heater controls will include an independent over-temperature shutoff feature.

Additional hazards are associated with hot surfaces. Hot surfaces will be thermally insulated to avoid possible skin contact to temperatures above $140^{\circ} \mathrm{F}$.

A Laboratory Instruction (LI) document will be prepared to provide work control related to operation of this flow loop. This document will also identify all hazards associated with research activities and loop operation along with engineering and administrative controls, required personal protective equipment (PPE) and training.

\section{ENGINEERING DESIGN CRITERIA}

\subsection{Code of Record}
A. ASME B31.3 - 2014 - Process Piping, Fluid Service Category - Normal Fluid Service
B. System Fluid and Purity: Deionized water, 1.0 to $0.1 \mu \mathrm{S} / \mathrm{cm}(1.0$ to $10 \mathrm{MegOhm} / \mathrm{cm})$.
C. System Operating Pressure: $15 \mathrm{MPa}$ (2176 psig)
D. System Design Pressure: 15.86 MPa (2300 psig)
E. System Design Flow Rate Range: $16.5 \mathrm{~L} / \mathrm{min}$ to $56.8 \mathrm{~L} / \mathrm{min}$ (4.4 gpm to $15 \mathrm{gpm})$
F. System Operating Temperature Range: $50^{\circ} \mathrm{C}$ to $325^{\circ} \mathrm{C}\left(122^{\circ} \mathrm{F}\right.$ to $\left.617^{\circ} \mathrm{F}\right)$
G. System Design Temperature: $371^{\circ} \mathrm{C}\left(700^{\circ} \mathrm{F}\right)$
H. pH Range: 6.9 to 7.4

\subsection{Quality Assurance (INL)}

A. The fabrication, examination, installation, and testing inspections shall be performed by the BEA owner's inspector.

B. BEA quality assurance to perform fabrication examination in accordance with ASME B31.32014, chapter 6 "inspection, examination, and testing" requirements.

C. BEA shall examine all materials and components and workmanship per ASME B31.3-2014, section 341 to ensure conformance to the design.

D. Visual inspection per section 344.2 shall be used.

E. All materials, components, and workmanship of subcontractor are subject to inspection by the BEA 01 in accordance with ASME B31.3-2014, section 340. 


\subsection{Design Basis}

A. The equipment and components within this process piping system design have been certified for use based on the ASME B31.3-2014 -- process piping code of record for listed or unlisted materials/components.

B. In the event the subcontractor selects another supplier for the equipment or components they must meet the following criteria:

1. All such equipment and components must be "listed" within ASME B31.3-2014 - process piping, fluid service category "normal fluid service." "Unlisted" equipment or components must be proven through engineering analysis that the equipment or component meets the temperature, pressure, and fluid compatibility of the process.

2. Any fit, form, or function related design changes resulting from the selection of a supplier different from that supplier used for the bases of design shall be made by the subcontractor at their own cost and responsibility.

3. Red-lined drawings provided by the subcontractor shall include these design changes.

4. The subcontractor must ensure dimensional requirements, electrical requirements, functionality, performance and all qualifications of said supplier to meet the design requirements set forth in these specifications and drawings.

5. See component/equipment matrix on drawings for a complete list of these items.

\subsection{Products}

A. All piping materials used for ASME B31.3-2014 services shall adhere to the requirements listed in ASME 831.3-2014, chapter 3 "materials."

B. All components used for ASME B31.3-2014 services shall be listed in table 326.1 "component standards" of this code. Any unlisted components shall comply with ASME b31.3-2014, section 302.2.3 "Unlisted Components." See component/equipment matrix on drawings for adherence to these requirements.

\section{INTERFACES TO CO-LOCATED SYSTEMS AND DETAIL}

The high-temperature high-pressure flow loop can serve as a thermal energy source for co-located systems in a hybrid energy system configuration. The "Process Feed" and "Process Return" lines indicated in Fig. 1 provide the piping connections needed for this purpose. In the DETAIL concept, hot water from the thermal hydraulic loop will flow into a heat exchanger, delivering high-temperature process heat to an intermediate heat transfer fluid such as DowTherm. This intermediate fluid will flow through a thermal network to deliver process heat to co-located systems such as the $25 \mathrm{~kW}$ hightemperature electrolysis demonstration facility and a thermal energy storage unit.

In addition to the thermal energy interface, the water loop instrumentation, data acquisition, and control systems will be interfaced to one or more digital real-time simulators located in the laboratory. This virtual interface will support dynamic studies of dynamic system behavior, impacts on electrical grids, and related topics. DETAIL will include additional energy systems such as an integrated microgrid and renewable energy systems including solar photovoltaics. The electrically heated hot water flow loop will be dynamically controlled to simulate nuclear fuel behavior under normal and off-normal operating conditions. DETAIL will be designed for characterization of complex system dynamics. The various components will be interfaced with digital real-time simulators for supervisory control and dynamic simulation of complete systems. 


\section{ENGINEERING DRAWINGS}

A complete set of engineering drawings of the hot water flow facility has been released. The drawings are based on a full 3D CAD model that was developed for the loop design. A few representative drawing cuts are provided here to provide a sense of the scale and layout of the facility within ESL D100. A plan view is presented in Fig. 4. The chiller is shown in the top of this view, located outside on the north side of the building. Coolant piping and the deaeration vent pipes are shown passing through the north wall. The flow loop is positioned on a skid, shown in three sections on the drawing. The DI water system is visible on the north (upward facing on the plan view) side of the skid. Cable trays for electrical conduit and industrial and drain lines are shown in the bottom of the drawing.

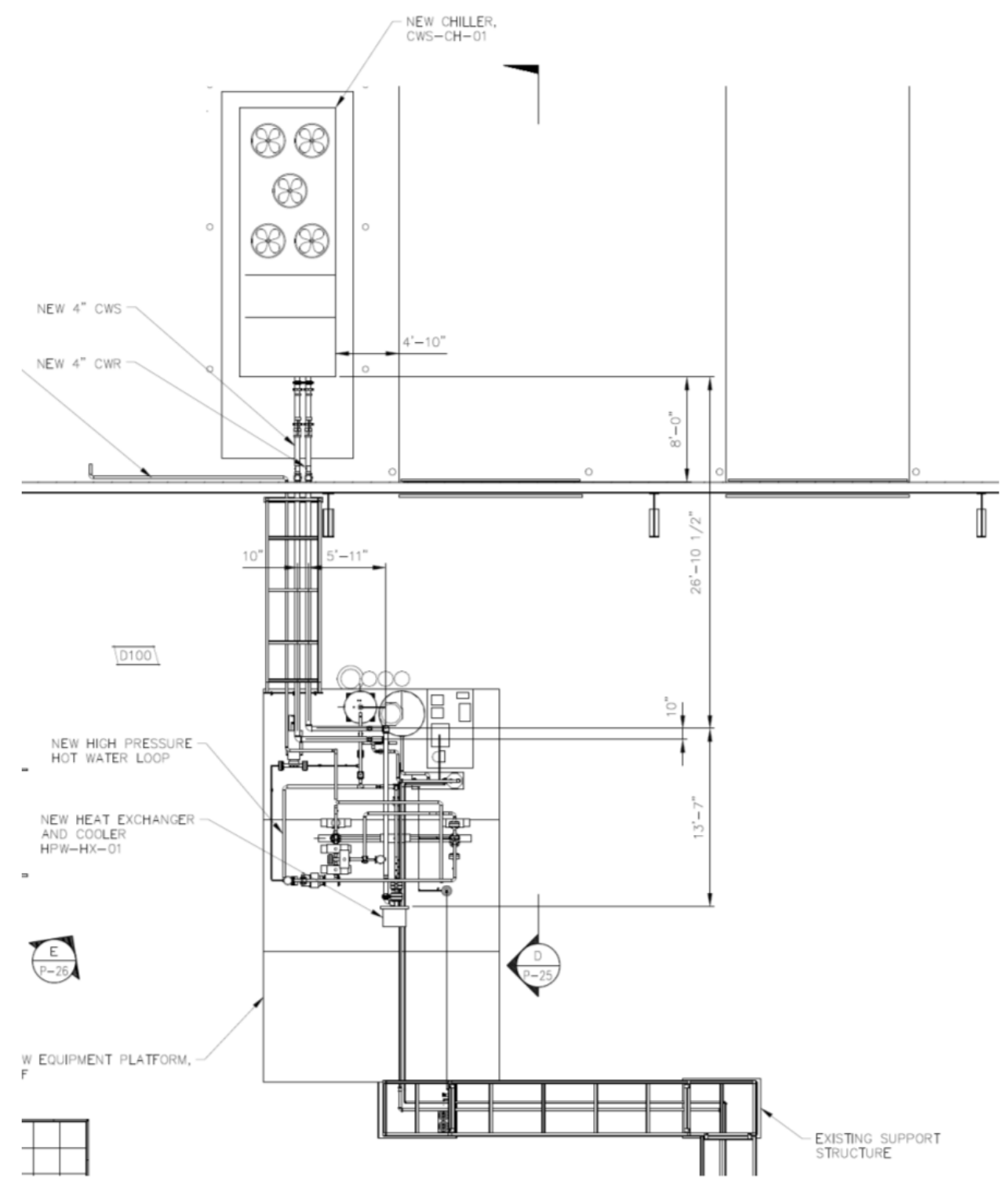

Figure 4. Plan view of flow loop and supporting systems. 


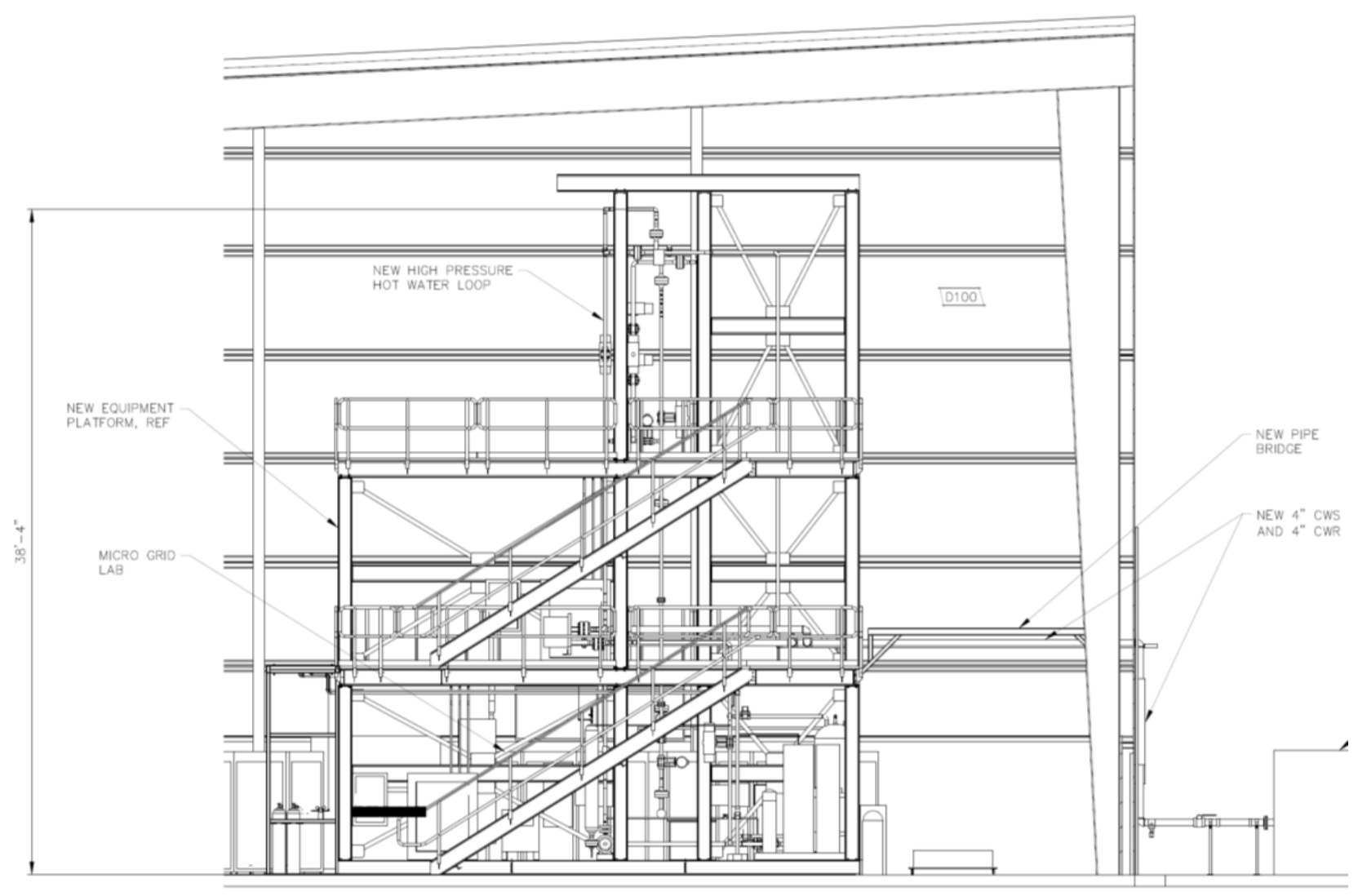

Figure 5. Elevation view of flow loop and supporting systems.

Construction of the water loop facility has been subdivided into two Phases. Phase 1 includes installation of general-purpose laboratory infrastructure/support systems necessary to perform any significant hardware testing in the High Bay. Scheduled to be completed by the end of FY17, Phase 1 covers installation of cable trays and supports, electrical conduit, a DI water system, drain lift station and the concrete pad for a chiller that will be located outside of the laboratory. The PWR loop is designed under Phase 2.

An elevation view of the flow loop and supporting systems is provided in Fig. 5. The slanted roof of the high bay ESL D100 laboratory is visible in the top of the figure. Note that the top of the flow loop is about $38 \mathrm{ft}$. above the floor. The framework surrounding the flow loop provides structural support for the piping and components plus personnel access to the valves and components. There are three levels including the skid.

An isometric view of the flow loop and supporting systems is provided in Fig. 6. In this view, the DI water system is in the lower left. Details of the support structure and personnel platforms can be seen. The mechanical integrity of the structure and platforms has been verified through appropriate stress analysis. 


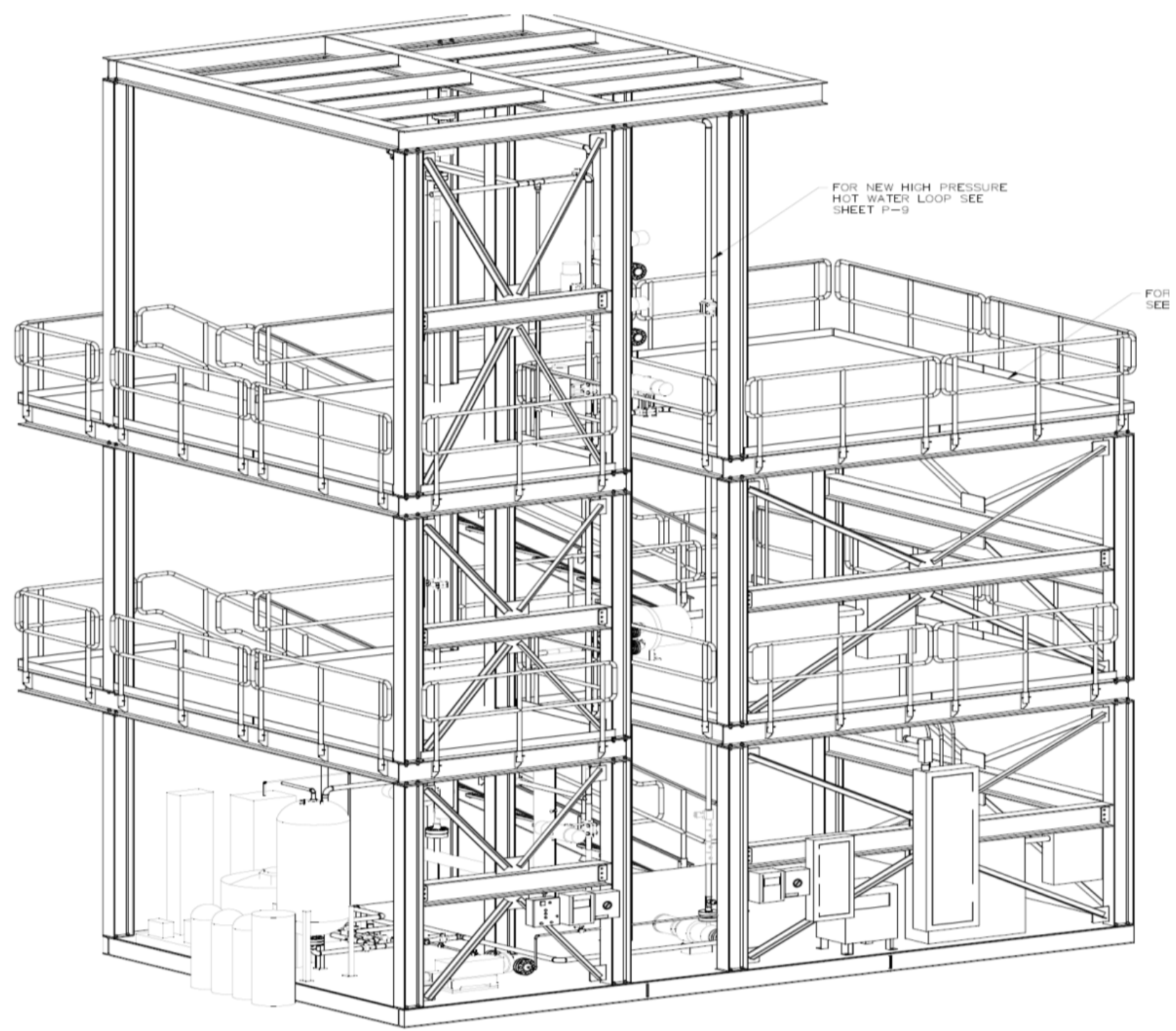

Figure 6. Isometric view of flow loop and supporting systems.

An isometric view of the flow loop and loop components without the surrounding structures and subsystems is shown in Fig. 7. The recuperator heat exchanger (HPW-HX-02) is shown near the top left of the figure. It is a compact PCHE design. In the forced circulation mode of operation, it serves as a recuperator. In the natural circulation mode, it provides heat rejection for buoyancy-driven flow. Its elevated location was required to support the natural circulation mode of operation. All eleven primaryloop motor-operated valves are visible in the drawing. The chiller heat exchanger (HPW-HX-01) located at mid-elevation is a helical coil design. Other large components visible in Fig. 7 include the auxiliary heater (HPW-AH-01), the accumulator (N2-TK-02), the high-pressure pump (HPW-PMP-02), plus the DI water system. Several pipe junctions are visible in the figure. Most of these junctions use class-2500 flanges. However, the high-temperature test section and the natural circulation measurement station use grayloc fittings for easier removal and replacement of those sections. 


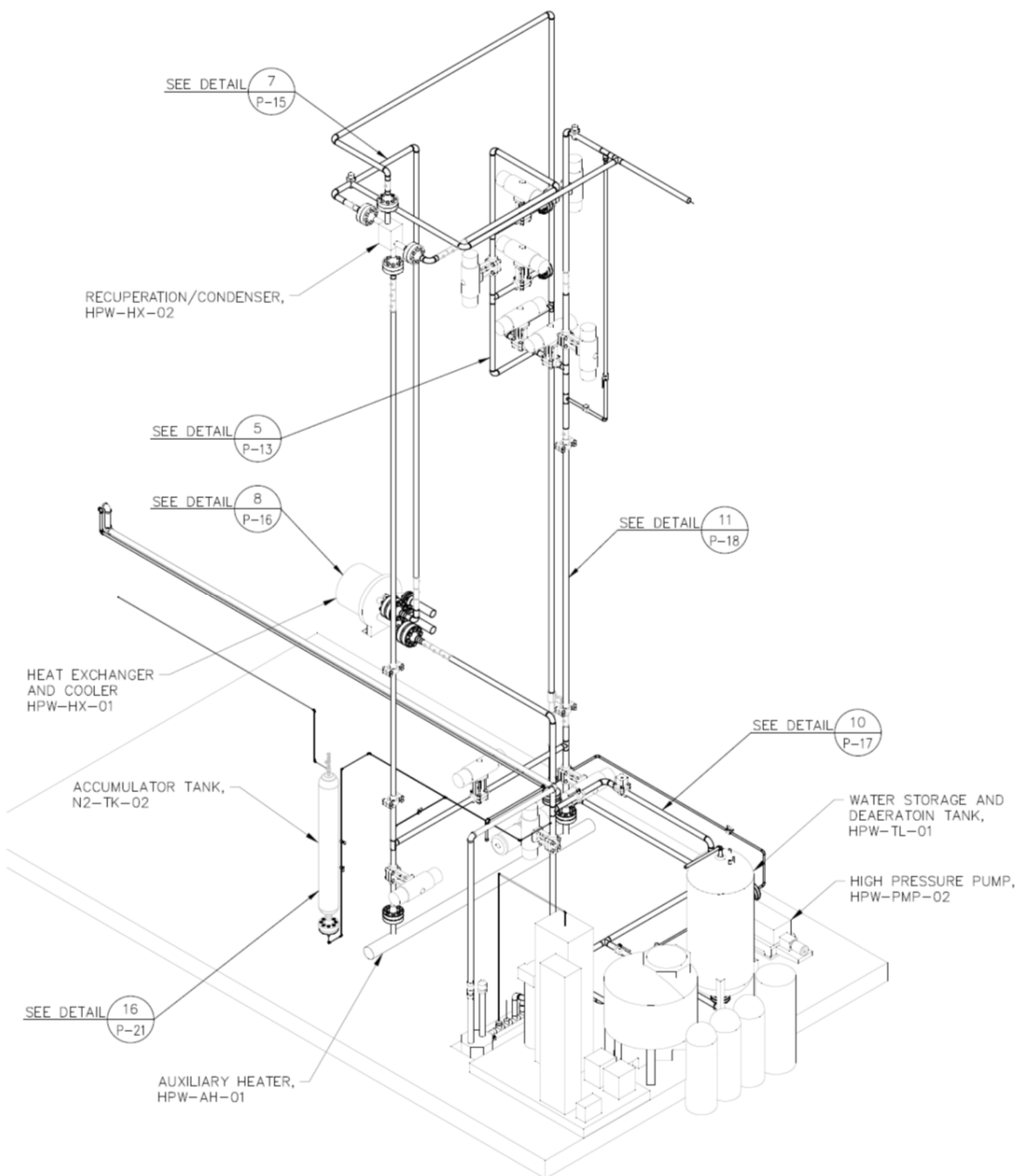

Figure 7. Isometric view of flow loop without support structure.

A second isometric view of the flow loop and loop components without the surrounding structures is presented in Fig. 8. This view is rotated 180 degrees from the view of Fig. 7. This figure provides a better view of the loop circulation pump (HPW-PMP-01) and the auxiliary heater (HPW-AH-01). 


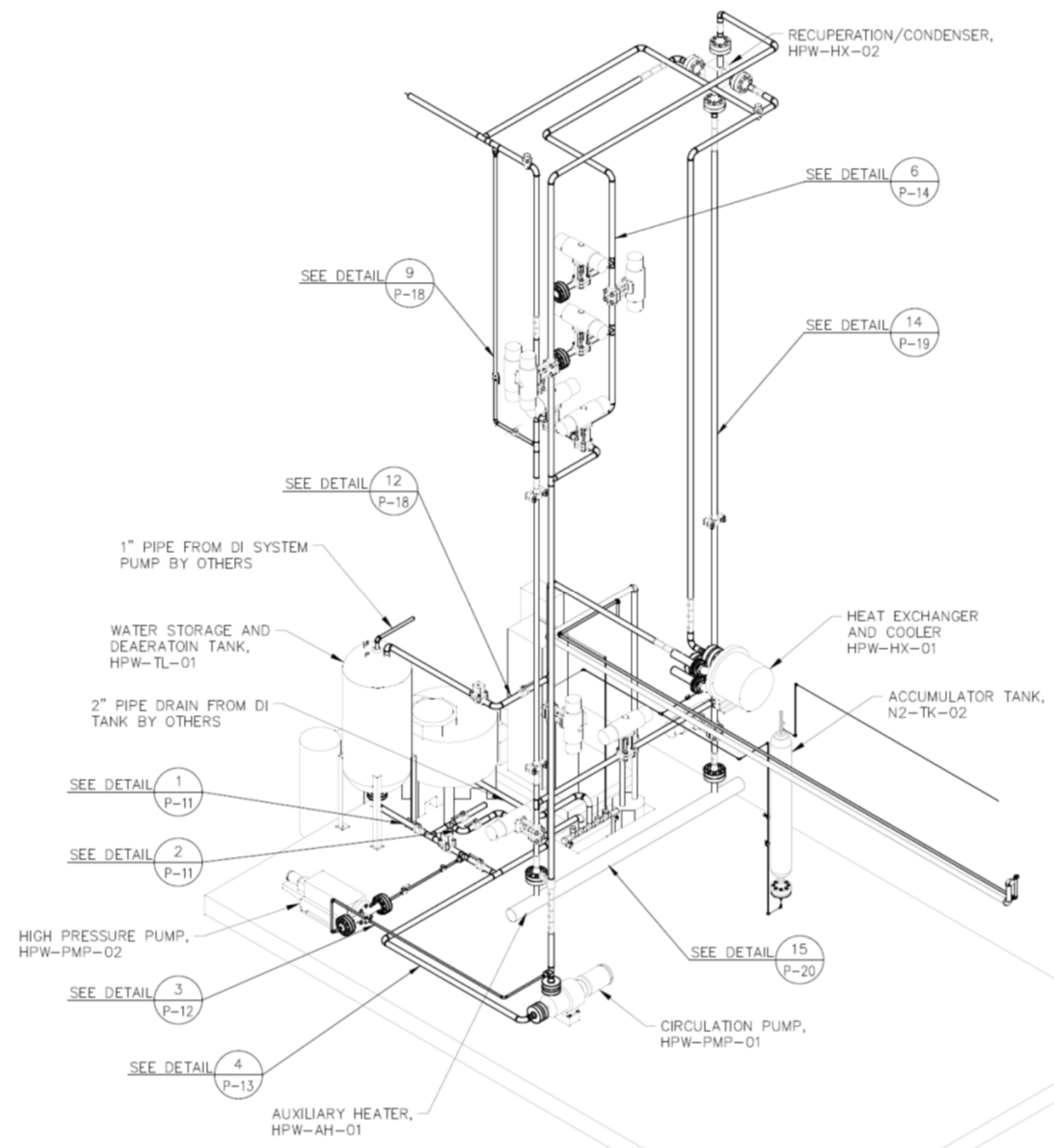

Figure 8. Rotated isometric view of flow loop without support structure.

\section{SHAKEDOWN TEST PLAN}

All test activities will be performed in accordance with appropriate work control, as specified in the Laboratory Instruction that will be prepared for this project. After delivery of the flow loop to the ESL D100 laboratory, shakedown testing will be performed. Activities to be completed during shakedown testing are listed below:

1. Checkout of all system instrumentation and data acquisition system.

2. Fill flow system with DI water; pressurize to 100 psig and perform leak checks.

3. Verify performance of motor-operated valves with computer controls. 
4. Initiate low-pressure forced circulation flow through the loop using the primary circulation pump; verify flow measurements over a range of pump speeds (controlled by variable frequency drive).

5. Verify performance of auxiliary heater at low pressure; perform energy balances to verify power settings versus mass flow rate and temperature rise.

6. Verify performance of chiller and chiller heat exchanger; perform energy balances on both primary and chiller loops.

7. Verify performance of recuperator; perform energy balances.

8. Verify performance of drain lift station.

9. Complete a deaeration procedure and validate with visual observations and dissolved oxygen measurements.

10. Pressurize the system following the steps outlined in the description of the pressurization system. This will be done in stages at increasing pressures until the design pressure is achieved.

11. Operate the system at full pressure and design flow rates and heating values to ensure full operability.

\section{PROJECT STATUS AND PATH FORWARD}

Phase 1, which covers installation of general-purpose laboratory infrastructure/support systems, is currently under way and will be completed by the end of FY17. Phase 2 includes the detailed design and final assembly of the PWR flow loop, supporting structures and personnel platforms, the chiller and associated piping. A final design review was held on August 29. Review comments were formally submitted into the INL document review database. These comments have all been addressed and the final design package will be delivered by the end of September. Funding for Phase 2 procurement, assembly, system operability checkout, shakedown testing and initial operation of the flow loop is requested for FY18.

\section{REFERENCES}

1. O’Brien, J. E., Sabharwall, P., Yoon, S., and Housley, G. K., "Strategic Need for a Multi-Purpose Thermal Hydraulic Loop for Support of Advanced Reactor Technologies," INL/EXT-14-33300.

2. Sabharwall, P., O’Brien, J. E., Yoon, S., and Sun, X., "Experimental Facility for Development of High-Temperature Reactor Technology: Instrumentation Needs and Challenges," European Physical Journal of Nuclear Science and Technology, Vol. 1, No. 14, Dec., 2015.

3. O’Brien, J. E., Sabharwall, P., and Yoon, S., "A Multi-Purpose Thermal Hydraulic Test Facility For Support of Advanced Reactor Technologies," ANS 2014 Winter Meeting and Nuclear Technology Expo, paper\# 11705, Anaheim, CA, Nov. 9-13, 2014.

4. O’Brien, J. E., Sabharwall, P., and Yoon, S., "Development of a Multi-Loop Flow and Heat Transfer Facility for Advanced Nuclear Reactor Thermal Hydraulic and Hybrid Energy System Studies," 2014 ASME International Mechanical Engineering Congress and Exposition, paper \# IMECE2014-39057, Montreal, Nov. 14-20, 2014. 


\section{APPENDIX A. COMPONENT AND INSTRUMENTATION DETAILS}

Table A-1. Component and Instrumentation Descriptions and Specifications.

\begin{tabular}{|c|c|c|c|}
\hline Nitrogen Gas Cylinder & 1 & $\begin{array}{l}\text { Pressure maintenance for } \\
\text { water loop; connected to the } \\
\text { gas side of the accumulator }\end{array}$ & $\begin{array}{l}6 \mathrm{~K} \text { cylinder ( } 6000 \mathrm{psi}) \text {, CGA } 677 \text { connection (this is not part of the } \\
\text { loop, it will be ordered separately from our industrial gas supplier at the } \\
\text { time of system qualification) }\end{array}$ \\
\hline $\begin{array}{l}\text { Self-venting regulator for } \mathrm{N}_{2} \\
\text { gas cylinder }\end{array}$ & 1 & $\begin{array}{l}\text { Maintain pressure at regulator } \\
\text { set point, with self-venting to } \\
\text { compensate for pressure } \\
\text { increase in flow loop due to } \\
\text { heating, etc. }\end{array}$ & $\begin{array}{l}\text { CGA } 677 \text { connection, self-venting; inlet pressure } 6000 \text { psi, outlet } \\
\text { pressure } 0-2300 \text { psi; example is Swagelok KHR Series }\end{array}$ \\
\hline Accumulator & 1 & $\begin{array}{l}\text { Maintain pressure in water } \\
\text { loop; dampen pressure } \\
\text { fluctuations }\end{array}$ & $\begin{array}{l}15 \mathrm{MPa} \text {, nominal; it should be rated for at least } 3000 \mathrm{psi} \text {; stainless steel, } \\
\text { nominal liquid capacity } \sim 20 \text { gal; gas capacity } \sim 4700 \mathrm{in}^{\wedge} 3 \text {; piston } \\
\text { accumulator Model PX2031008B10GXF-R1 from Accumulators, Inc. } \\
\text { is an example. }\end{array}$ \\
\hline High-pressure pump & 1 & $\begin{array}{l}\text { Establish initial pressure in } \\
\text { flow loop, while compressing } \\
\text { the gas in the accumulator }\end{array}$ & $\begin{array}{l}\text { Compression rating to } 3000 \text { psi, low flow rate; Pulsafeeder Pulsa Series } \\
7660 \text { with } 0.56 \text {-inch piston area is an example }\end{array}$ \\
\hline Variable frequency drive & 1 & Pump speed control & $\begin{array}{l}\text { Allow for smooth variation in pump speed; } 480 \mathrm{~V}, 3 \text {-phase; will } \\
\text { probably be purchased as a system with the water circulation pump; } \\
\text { must be able to communicate with our DAS }\end{array}$ \\
\hline $\mathrm{H}_{2} \mathrm{O}-\mathrm{H}_{2} \mathrm{O}$ Recuperator & 1 & $\begin{array}{l}\text { Water-to-water recuperative } \\
\text { heat exchanger, allowing } \\
\text { water pump and flow meter to } \\
\text { operate at low Temp. }\end{array}$ & $\begin{array}{l}\text { Operating pressure } 15 \mathrm{MPa} \text {, heat duty: } 250 \mathrm{~kW} \text { (at nominal flow rate } \\
\text { and heater power of } 83.5 \mathrm{~kW} \text { ); maximum heat duty: } 525 \mathrm{~kW} \text { (at } 9.2 \\
\text { gpm, } 175 \mathrm{~kW} \text { auxiliary heater power and no process heat removal); } \\
\text { water-to-water; hot side inlet/outlet temperatures: } 325 / 119^{\circ} \mathrm{C} \text {, cold-side }\end{array}$ \\
\hline
\end{tabular}




\begin{tabular}{|c|c|c|c|}
\hline & & & $\begin{array}{l}\text { water inlet/outlet temperatures: } 50 / 256^{\circ} \mathrm{C} \text { at nominal flow rate of } 994 \\
\mathrm{~kg} / \mathrm{hr} \text {; flow rate range } 4-15 \mathrm{gpm} \text {; wetted surfaces stainless steel; we } \\
\text { now have a quote for a PCHE from VPEI at } \sim \$ 18 \mathrm{k} \text {; with a pressure } \\
\text { drop across the PCHE of } \sim 6 \mathrm{psid} \text {. }\end{array}$ \\
\hline High Temp Test Section & 1 & $\begin{array}{l}\text { flow, heat transfer, and } \\
\text { materials studies }\end{array}$ & $\begin{array}{l}15 \mathrm{MPa}, 325^{\circ} \mathrm{C} \text {; this test section will be represented by a 2-inch NPS } \\
\text { flanged (or grayloc) pipe section (spool piece) in the initial design and } \\
\text { during loop qualification; length: } 12 \mathrm{ft} \text {; all loop piping will be SS316; }\end{array}$ \\
\hline $\begin{array}{l}\text { Heat rejection heat } \\
\text { exchanger/cooler }\end{array}$ & 1 & $\begin{array}{l}\text { primary heat rejection heat } \\
\text { exchanger }\end{array}$ & $\begin{array}{l}175 \mathrm{~kW} \text { heat duty rating or higher, } 15 \mathrm{MPa} \text { (primary side), secondary } \\
\text { side can be at low (near-ambient) pressure, nominal conditions at a } \\
\text { primary-side water flow rate of } 994 \mathrm{~kg} / \mathrm{hr} \text { : hot side inlet } 118^{\circ} \mathrm{C} \text {, outlet } \\
50 \mathrm{C} \text {, which corresponds to } 83.5 \mathrm{~kW} \text { heat rejection (nominal); cooling } \\
\text { water inlet at } 20 \mathrm{C} \text {, with a minimum flow rate rating of } 15 \mathrm{gpm} \text {; } \\
\text { stainless steel }\end{array}$ \\
\hline $\begin{array}{l}\text { Cooling Water Pump (for } \\
\text { chiller) }\end{array}$ & 1 & prime mover for water loop & $\begin{array}{l}20^{\circ} \mathrm{C}, 0.2 \mathrm{MPa}, 16 \mathrm{gpm}, ; \text { (this pump may be purchased as part of the } \\
\text { chiller system) }\end{array}$ \\
\hline Chiller, air-cooled & 1 & $\begin{array}{l}\text { Provides cooling water for the } \\
\text { secondary side of the cooler }\end{array}$ & $\begin{array}{l}0.2 \mathrm{MPa} \text {, water flow rate up to } 16 \mathrm{gpm} \text { minimum at } 20 \mathrm{C}, \Delta \mathrm{T}=50^{\circ} \mathrm{C} \text { or } \\
\text { less; must provide a minimum of } 175 \mathrm{~kW}(\sim 60 \text { ton }) \text { heat rejection; this } \\
\text { unit will be located outdoors adjacent to ESL; there is a possibility that } \\
\text { it may be purchased using general-purpose funding for support of } \\
\text { multiple projects; }\end{array}$ \\
\hline $\begin{array}{l}\text { Steam/Water Chemistry } \\
\text { Control Section }\end{array}$ & 1 & $\begin{array}{l}\text { Control chemistry of water } \\
\text { introduced into the flow loop }\end{array}$ & $\begin{array}{l}0.1 \mathrm{MPa}, 20^{\circ} \mathrm{C} \text {; ion exchange }+ \text { reverse osmosis system; resistivity } \\
\text { specification } 1.0-0.1 \mu \mathrm{S} / \mathrm{cm} \text {; system will be supplied by Evoqua } \\
\text { (Andy Tyler) }\end{array}$ \\
\hline $\begin{array}{l}\text { Water Storage and } \\
\text { Deaeration Tank }\end{array}$ & 1 & $\begin{array}{l}\text { storage of treated water for } \\
\text { entire loop }\end{array}$ & $\begin{array}{l}0.15 \mathrm{MPa}, 20^{\circ} \mathrm{C} \text {, Approximate dimensions: } \mathrm{D}=0.76 \mathrm{~m}, \mathrm{H}=1.78 \mathrm{~m} \text {, } \\
\mathrm{V}=810 \mathrm{~L} \\
\text { Stainless steel; (may use polyethylene) }\end{array}$ \\
\hline
\end{tabular}




\begin{tabular}{|c|c|c|c|}
\hline Low Temp MOVs & 3 & 2-in NPS 160 lines & $15 \mathrm{MPa}, 50^{\circ} \mathrm{C}$, motor-operated, remote controllable ball valves \\
\hline $\begin{array}{l}\text { Other valves (HVs), not on } \\
\text { main 2-in piping }\end{array}$ & 19 & & Specs depend on location \\
\hline $\begin{array}{l}\text { Low-temperature, high- } \\
\text { pressure Pressure Relief } \\
\text { Valves }\end{array}$ & 2 & $\begin{array}{l}\text { At HP pump outlet, on } \\
\text { accumulator }\end{array}$ & $15 \mathrm{MPa}, 50^{\circ} \mathrm{C}$ \\
\hline $\begin{array}{l}\text { High-temperature, high- } \\
\text { pressure Pressure Relief } \\
\text { Valves }\end{array}$ & 2 & $\begin{array}{l}\text { On heater (part of heater } \\
\text { system), primary PRV, } \\
\text { secondary PRV (NC loop) }\end{array}$ & $15 \mathrm{MPa}, 350^{\circ} \mathrm{C}$ \\
\hline Check Valves & 3 & & $\begin{array}{l}15 \mathrm{MPa}, 50 \mathrm{C}, 1500 \# \text { class SS316; Additional locations for check valves } \\
\text { may be identified }\end{array}$ \\
\hline Piping & & & $15 \mathrm{MPa}, 350^{\circ} \mathrm{C}$, NPS 2 , schedule 160, SS 316 \\
\hline $\begin{array}{l}\text { Flanges - high-temperature } \\
\text { sections }\end{array}$ & & & $15 \mathrm{MPa}, 350^{\circ} \mathrm{C}, \mathrm{SS} 316$, class $2500 \#$ \\
\hline $\begin{array}{l}\text { Flanges - low-temperature } \\
\text { sections }\end{array}$ & & & $15 \mathrm{MPa}, 50^{\circ} \mathrm{C}, \mathrm{SS} 316$, class $1500 \#$ \\
\hline $\begin{array}{l}\text { Thermal Insulation - high } \\
\text { temperature sections }\end{array}$ & & $\begin{array}{l}\text { Minimize heat loss from HT } \\
\text { piping sections; provide safe } \\
\text { touch temperature }\end{array}$ & $\begin{array}{l}\text { Straight pipe sections should be insulated with 2-inch thickness of } \\
\text { industrial pipe insulation such as Owens-Corning SSL II with ASJ Max } \\
\text { no-wrap pipe insulation (suitable for process temp up to } 538^{\circ} \mathrm{C} \text { ); } \\
\text { insulation thermal conductivity at mean temperature } 0.06 \mathrm{~W} / \mathrm{m} * \mathrm{~K} \text { or } \\
\text { lower; custom insulation jackets may be required for some high- } \\
\text { temperature components such as valves, heat exchangers, test section; } \\
\text { custom jackets are available from Thermaxx }\end{array}$ \\
\hline
\end{tabular}

Instrumentation

\begin{tabular}{|l|c|l|l|}
\hline \multicolumn{1}{|c|}{ Instrument } & \#Req'd & \multicolumn{1}{|c|}{ Purpose } & \multicolumn{1}{c|}{ Specification } \\
\hline $\begin{array}{l}\text { Absolute Pressure } \\
\text { transducers }\end{array}$ & 6 & $\begin{array}{l}\text { On-line loop pressure } \\
\text { monitoring }\end{array}$ & $\begin{array}{l}\text { Range: 0-20 MPa, liquid service, 0-5 VDC output; see Honeywell Model } \\
\text { TJE, 3000 psi range (in high-temperature zone, transducer will have to be } \\
\text { thermally isolated from the process fluid) }\end{array}$ \\
\hline Differential Pressure & 6 & On-line monitoring of delta-P & $\Delta$ P Range TBD, wet-wet differential pressure transducers, line pressure \\
\hline
\end{tabular}




\begin{tabular}{|l|c|l|l|}
\hline transducers & & $\begin{array}{l}\text { across heat exchangers, heater, } \\
\text { and test section }\end{array}$ & $\begin{array}{l}\text { rating 20 MPa; see Honeywell Model HL-Z (in high-temperature zone, } \\
\text { transducer will have to be thermally isolated from the process fluid) }\end{array}$ \\
\hline thermocouples & 8 & $\begin{array}{l}\text { On-line loop temperature } \\
\text { monitoring }\end{array}$ & $\begin{array}{l}1 / 8 \text {-inch, Type K, SS sheath (mounting method for insertion into the flow } \\
\text { will be via 1/2-inch NPT ports) }\end{array}$ \\
\hline $\begin{array}{l}\text { Flow meter - primary } \\
\text { loop }\end{array}$ & 1 & $\begin{array}{l}\text { On-line loop flow rate } \\
\text { measurement }\end{array}$ & $\begin{array}{l}\text { Line pressure 20 MPa rating, 1500\# class flanges, Flow Technology turbine } \\
\text { flow meter FT12 with extended range calibration, ball bearing/RF pickoff } \\
\text { with frequency-to-DC converter for DC voltage output, 0.25 - 25 gpm flow } \\
\text { rate range }\end{array}$ \\
\hline $\begin{array}{l}\text { Flow meter - cooling } \\
\text { water }\end{array}$ & 1 & $\begin{array}{l}\text { On-line monitoring of cooling } \\
\text { water flow rate }\end{array}$ & $\begin{array}{l}\text { This item may be included with the chiller; flow rate range: } 0-10 \text { gpm, } \\
\text { low-pressure ( .15 MPa rating) }\end{array}$ \\
\hline Dissolved $\mathrm{O}_{2}$ sensor & 2 & & \\
\hline Conductivity sensor & 2 & & \\
\hline Nat circ flow meter & 1 & & \\
\hline Nat circ orifice plate & 1 & & \\
\hline
\end{tabular}

